\title{
Effects of abomasal infusion of nicotinic acid on responses to glucose and $\beta$-agonist challenges in underfed lactating cows
}

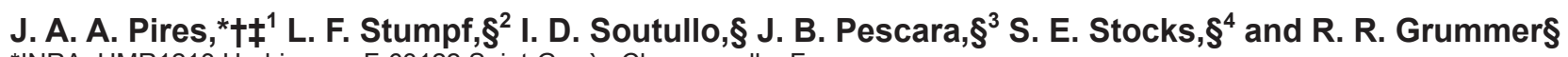 \\ *INRA, UMR1213 Herbivores, F-63122 Saint-Genès Champanelle, France \\ †Clermont Université, VetAgro Sup, BP 10448, F-63000 Clermont-Ferrand, France \\ łUniversité de Lyon, VetAgro Sup, UMR1213 Herbivores, F-69280 Marcy l'Etoile, France \\ $\S$ Department of Dairy Science, University of Wisconsin, Madison 53706
}

\section{ABSTRACT}

The objectives were to assess the use of nicotinic acid (NA) to chronically (i.e., $74 \mathrm{~h}$ ) manipulate plasma nonesterified fatty acid (NEFA) concentrations in partially feed-restricted lactating cows, determine whether the reduction of plasma NEFA altered responses to i.v. glucose tolerance test (ivGTT) and whether NA would attenuate an acute lipolytic stimuli of a $\beta$-agonist challenge (ivBAC). Eight lactating dairy cows $[244 \pm 31$ d in milk; $696 \pm 63 \mathrm{~kg}$ of body weight (BW)] were blocked by breed and body condition score $(3.2 \pm 0.4)$ and randomly assigned to a sequence of 2 treatments in a crossover design. Treatments were 74 -h continuous abomasal infusion of NA solution $(3 \mathrm{mg} / \mathrm{h}$ per $\mathrm{kg}$ of $\mathrm{BW}$ ) as an antilipolytic agent to decrease plasma NEFA concentrations or the same volume of water $(200 \mathrm{~mL} / \mathrm{h})$, concomitant with partial feed restriction. From 0 to $74 \mathrm{~h}$ of each experimental period, cows were feed-restricted to $33 \%$ of the ad libitum intake recorded during the prior $5 \mathrm{~d}$. An ivGTT $(0.25 \mathrm{~g} / \mathrm{kg}$ of BW of glucose i.v.) and an ivBAC (4 nmol $/ \mathrm{kg}$ of $\mathrm{BW}$ of isoproterenol hydrochloride, i.v.) were performed at 48 and $72 \mathrm{~h}$, respectively. Intake was $24.1,8.2,8.0$, and $8.0 \mathrm{~kg}$ of dry matter/d before restriction, on d 1,2 and 3 , respectively. Nicotinic acid decreased plasma NEFA and increased insulin and glucose concentrations during feed restriction. Nicotinic acid also led to greater glucose and insulin response areas under the curve during ivGTT [glucose: 6,562 vs. $5,056(\mathrm{mg} / \mathrm{dL}) \times 180$ min; insulin: 6,042 vs. $2,502(\mu \mathrm{IU} / \mathrm{mL}) \times 180 \mathrm{~min}]$ and ivBAC [glucose: 535 vs. $240(\mathrm{mg} / \mathrm{dL}) \times 120 \mathrm{~min}$; insulin: 1,283 vs. $222(\mu \mathrm{IU} / \mathrm{mL}) \times 120 \mathrm{~min}]$, and enhanced NEFA area under the curve during ivBAC $[45,521$ vs.

Received August 25, 2015

Accepted November 22, 2015.

${ }^{1}$ Corresponding author: jose.pires@clermont.inra.fr

${ }^{2}$ Current address: MSD Animal Health, 28027 Madrid, Spain.

${ }^{3}$ Current address: Elanco Animal Health, 8264 Sao Paulo, Brazil.

${ }^{4}$ Current address: Barton, Kiefer and Associates, Seville, OH 44273. $22,862(\mu \mathrm{Eq} / \mathrm{L}) \times 120 \mathrm{~min}]$. Milk, fat, and protein yields (29.1, 1.2 , and $0.93 \mathrm{~kg}$ on $\mathrm{d}-2$, respectively) decreased to $17.9,0.81$, and $0.56 \mathrm{~kg}$ for control, and 11.5, 0.54, and $0.39 \mathrm{~kg}$ for NA on d 3, respectively. Nicotinic acid may have decreased production by inhibiting the supply of NEFA for energy and milk fat synthesis. Milk urea nitrogen was increased by NA on d 2 (12.8 vs. 19.1 $\mathrm{mg} / \mathrm{dL})$ and $\mathrm{d} 3(11.6$ vs. $17.8 \mathrm{mg} / \mathrm{dL})$, probably due to a greater reliance on mobilized amino acids. Somatic cell count was increased by NA on d 3 (187 vs. 848 $\times 1,000$ cells $/ \mathrm{mL}$ ). Patterns of glucose and insulin concentration observed during $74 \mathrm{~h}$ of NA infusion reflect a state of insulin resistance, which contrasts with shorterterm responses in nonlactating cows. Data suggest that long-term supraphysiological infusion of NA affected intermediary metabolism beyond antilipolysis and did not inhibit acute lipolytic stimuli of ivBAC.

Key words: bovine, nicotinic acid, nonesterified fatty acids, insulin resistance, lipolysis

\section{INTRODUCTION}

Periparturient dairy cows experience profound physiologic adaptations that alter hormonal profile and tissue responsiveness and sensitivity to key regulatory hormones. These adaptations promote mobilization of body reserves and the onset of insulin resistance to spare glucose for fetal growth and milk synthesis (Bauman and Currie, 1980; Bell and Bauman, 1997; Chilliard et al., 2000). As a result, plasma nonesterified fatty acids (NEFA) concentrations gradually increase during the last 2 wk of gestation, followed by a sharp rise at calving (Grummer, 1993; Vazquez-Añon et al., 1994). At the same time, there is a gradual decline in DMI, leading to negative energy balance at calving and during early lactation (Doepel et al., 2002; Hayirli et al., 2003; Rabelo et al., 2003). Negative repercussions of exaggerated plasma NEFA concentrations in periparturient dairy cows have been widely documented. The liver can remove 17 to $22 \%$ of NEFA supply from the bloodstream in periparturient cows (Reynolds et al., 
2003); therefore, it is susceptible to fatty acid overload (Grummer, 1993; Reynolds et al., 2003), as demonstrated by the acute increase in liver triglyceride content that is closely associated with the plasma NEFA surge at calving (Vazquez-Añon et al., 1994). Hepatocyte triglyceride accumulation impairs gluconeogenesis and detoxification of ammonia via ureagenesis in vitro (Cadorniga-Valino et al., 1997; Strang et al., 1998) and precedes experimental induction of ketosis in vivo (Veenhuizen et al., 1991). Enhanced hepatic fatty acid oxidation may downregulate appetite centers and affect DMI (Allen and Piantoni, 2013), and elevated NEFA concentrations depress cell-mediated immune function in vitro (Lacetera et al., 2004). Therefore, management of lipomobilization in periparturient cows has been a major concern for the dairy industry. We have speculated that rumen-protected nicotinic acid (NA) could be used to attenuate lipolytic rates around calving and prevent metabolic disorders associated with intense fat mobilization (Pires and Grummer, 2007), and we have compared abomasal infusions versus a rumen-protected form of NA using a feed-restriction model (Pescara et al., 2010). Subsequent research assessed the effects of feeding rumen-protected forms of niacin on metabolism and performance of periparturient cows. Rumenprotected NA (12 or $24 \mathrm{~g} / \mathrm{d}$, containing $65 \% \mathrm{NA}$ ) decreased plasma NEFA (Morey et al., 2011; Yuan et al., 2012), resulting in lower milk fat content and ECM secretion (Yuan et al., 2012), indicating a decreased lipolytic state during the first 2 wk of lactation.

Previous research addressed the relationship between elevated plasma NEFA concentration and insulin resistance in nonlactating Holstein cows. Induction of hyperlipidemia impaired the response to insulin in fed nonlactating Holstein cows (Pires et al., 2007b). To test whether lowering plasma NEFA availability would enhance the response to insulin, we developed an animal model using abomasal infusion of NA to inhibit lipolysis and decrease plasma NEFA concentration in feed-restricted cows (Pires and Grummer, 2007). In a short-term study (up to $11 \mathrm{~h}$ ), a decrease of plasma NEFA concentration by NA enhanced whole-body response to insulin in feed-restricted nonlactating cows, further implicating plasma NEFA as a causal factor of insulin resistance in the bovine (Pires et al., 2007a). In the current study, we hypothesized that NA would exert long-term antilipolytic effects in lactating cows under negative energy balance, the sustained reductions of plasma NEFA would change whole-body responses to insulin, and NA would attenuate the plasma NEFA surge due to acute lipolytic stimuli. The objectives were to assess the use of NA to chronically (i.e., $74 \mathrm{~h}$ ) manipulate plasma NEFA concentrations in partially feed-restricted lactating cows, to determine whether this reduction of plasma NEFA altered responses to an i.v. glucose tolerance test (ivGTT), and whether NA would modify the acute lipolytic effects of an i.v. $\beta$-agonist challenge (ivBAC).

\section{MATERIALS AND METHODS}

\section{Experimental Design}

The University of Wisconsin College of Agriculture and Life Sciences Institutional Animal Care and Use Committee approved the research protocol. Eight lactating dairy cows $(244 \pm 31 \mathrm{DIM} ; 696 \pm 63 \mathrm{~kg}$ of $\mathrm{BW}$; mean $\pm \mathrm{SD})$ were blocked by BCS $(3.2 \pm 0.4$; mean \pm SD; NRC, 2001) and breed (six pure Holstein and two 3/4 Holstein:1/4 Jersey crossbred), and were randomly assigned to a sequence of 2 treatments in a crossover design. Treatments were 74 -h continuous abomasal infusion of NA solution $(3 \mathrm{mg} / \mathrm{h}$ per $\mathrm{kg}$ of BW) as an antilipolytic agent to decrease plasma NEFA concentrations or the same volume of water (200 $\mathrm{mL} / \mathrm{h}$ ) using a syringe pump (model PHD 2000; Harvard Apparatus Inc., Holliston, MA). Treatments were concomitant with partial feed restriction. The rate of NA infusion corresponded to $50 \%$ of the amount previously given as hourly boluses (Pires et al., 2007a) and was identical to the continuous infusion rate used in a trial with nonlactating feed-restricted cows (Pescara et al., 2010). Infusions were interrupted twice daily $(<30$ min) for milking, and the 2 experimental periods were separated by 15 d. Nicotinic acid (99.7\% purity; Adisseo USA Inc., Alpharetta, GA) was diluted in water as described previously (Pires and Grummer, 2007). Cows were rumen-cannulated and fitted with an abomasal infusion tube (Gressley et al., 2006) to allow continuous infusions of treatments directly into the abomasum and prevent ruminal degradation of NA. For logistical reasons, 2 cows from each treatment sequence were randomly allocated to a group of 4 animals that initiated the experimental protocol $1 \mathrm{wk}$ apart.

From 0 to $74 \mathrm{~h}$ of each experimental period, cows were feed-restricted to $33 \%$ of the ad libitum intake recorded during the $5 \mathrm{~d}(\mathrm{~d}-7$ to -3$)$ before the experimental period. Partial feed restriction was employed to stimulate mobilization of body reserves and increase plasma NEFA concentration. This model of partial feed restriction was used to assess whether continuous abomasal NA infusion would exert chronic antilipolytic effects. Starting at least 2 wk before the first experimental period, cows were offered a TMR composed of $30.4 \%$ alfalfa silage, $34 \%$ corn silage, $9.8 \%$ whole cottonseed, and $25.8 \%$ concentrate, vitamin and mineral mixture (DM basis), containing 32.1\% NDF, $22.8 \%$ $\mathrm{ADF}, 17.5 \% \mathrm{CP}, 4.7 \%$ fat, and $1.62 \mathrm{Mcal}$ of $\mathrm{NE}_{\mathrm{L}} / \mathrm{kg}$ 
of DM. This diet was formulated to sustain $32 \mathrm{~L} / \mathrm{d}$ of milk production for a mature Holstein cow at ad libitum intake (NRC, 2001). Daily feed allotment was divided in 2 equal portions and offered at $0730 \mathrm{~h}$ and $1800 \mathrm{~h}$ throughout the trial. Vitamins and minerals were supplemented during periods of feed restriction to meet or exceed requirements (NRC, 2001), assuming a $50 \%$ reduction of milk production. Cows were allowed free access to water and trace mineralized salt block throughout the duration of the experiment.

On the day before initiation of feed restriction and administration of treatments, catheters (polyurethane 14-gauge $\times 13 \mathrm{~cm}$; Mila International Inc., Erlanger, $\mathrm{KY}$ ) were fitted into a jugular vein of each cow and attached to an extension set (Baxter International Inc., Deerfield, IL; $86 \mathrm{~cm}, 3.9 \mathrm{~mL}$ vol.). Catheters were flushed with $10 \mathrm{~mL}$ of heparinized saline $(100 \mathrm{IU} / \mathrm{mL})$ plus 0.4 $\mathrm{mg} / \mathrm{mL}$ of Naxcel (Pfizer Inc., New York, NY) at least twice daily to maintain patency and prevent bacterial growth, or with diluted heparinized saline only (10 IU/ $\mathrm{mL}$ ) during periods of frequent sampling for ivGTT and ivBAC. An ivGTT $(0.25 \mathrm{~g} / \mathrm{kg}$ of BW of glucose i.v.; $50 \%$ wt/vol; Phoenix Scientific Inc., St. Joseph, MO) was performed at $48 \mathrm{~h}$ of partial feed restriction and infusion of treatments. A $\beta$-agonist challenge (4 $\mathrm{nmol} / \mathrm{kg}$ of BW of isoproterenol hydrochloride, i.v.; Isuprel, Hospira Inc., Lake Forest, IL) was performed at 72 $\mathrm{h}$. This isoproterenol bolus caused a lipolytic response and a transient increase in plasma NEFA in underfed nonlactating heifers (Ferlay and Chilliard, 1999) that was similar in magnitude to that observed at calving (Vazquez-Añon et al., 1994). Glucose was infused over $1.4 \pm 0.2 \mathrm{~min}$ for ivGTT, whereas isoproterenol was diluted with sterile saline to $0.05 \mathrm{mg} / \mathrm{mL}$ and individual doses were infused over $0.5 \pm 0.1 \mathrm{~min}$ for ivBAC (mean $\pm \mathrm{SD}$ ). Catheters were flushed with $50 \mathrm{~mL}$ of sterile saline to ensure complete infusion of glucose and isoproterenol and prevent contamination of subsequent samples. Challenges were performed $13 \mathrm{~h}$ after evening feed was offered, and morning feeding was delayed until after the last blood sample was collected. Body weight was recorded each period, on 2 consecutive days before initiation of feed restriction, 5 to $6 \mathrm{~h}$ after morning feed was offered, and was used to calculate individual NA infusion rate and glucose and isoproterenol doses.

Blood samples were collected before morning feeding immediately before initiation of partial feed restriction and continuous abomasal infusion of water or nicotinic acid, at $24 \mathrm{~h}$, at $-15,-5,0,7,10,15,20,30,40,50,60$, $75,90,120,150$, and 180 min relative to administration of glucose for ivGTT (performed at $48 \mathrm{~h}$ ), and at -15 , $-5,0,2.5,5,7.5,10,15,20,25,30,45,60,75,90,105$, and $120 \mathrm{~min}$ relative to administration of isoproterenol for ivBAC (performed at $72 \mathrm{~h}$ ). Blood samples collected from one cow during ivGTT were not usable due to sampling problems, and data from this animal were not included for assessment treatment effects on d 2 of each period. After collection of the last blood sample of ivBAC, cows were offered $5 \mathrm{~kg}$ of alfalfa hay, followed by $40 \mathrm{~kg}$ of regular TMR (as fed) $1 \mathrm{~h}$ later. Due to the mixture of hay and TMR, it was not feasible to measure DMI accurately on d 4 of each period.

Blood was drawn from catheters using disposable 20-mL syringes and transferred to evacuated tubes (Becton Dickinson, Franklin Lakes, NJ). Tubes for collection of plasma $(6 \mathrm{~mL}$; containing $12 \mathrm{mg}$ of potassium oxalate and $15 \mathrm{mg}$ of sodium fluoride as a glycolytic inhibitor) were kept on ice until centrifugation at 920 $\times g$ at $4^{\circ} \mathrm{C}$ for $20 \mathrm{~min}$. Tubes for collection of serum $(6$ $\mathrm{mL}$; containing clot activator) were allowed to clot at room temperature and centrifuged at $2,050 \times g$ at $20^{\circ} \mathrm{C}$ for $30 \mathrm{~min}$. Blood plasma was analyzed for glucose and NEFA, and serum was analyzed for insulin as described previously (Pires et al., 2007b). Intra- and interassay CV were 3.0 and $3.1 \%$ for glucose, 2.6 and $4.3 \%$ for NEFA, and 5.9 and $10.5 \%$ for insulin, respectively. Plasma samples collected at -15 and -5 min relative to ivGTT and ivBAC were analyzed for BHB (Gibbard and Watkins, 1968; intraassay $\mathrm{CV}=2.5 \%$ ). Metabolite and insulin concentrations at 48 and $72 \mathrm{~h}$ relative to initiation of treatment administration and feed restriction were calculated by averaging values from samples collected 15 and 5 min before ivGTT and ivBAC, respectively.

Milk weights were measured daily and milk samples were collected during a.m. and p.m. milkings on d -2 , 1,2 , and 3 of each period, corresponding approximately to -37 and $-25 \mathrm{~h}(\mathrm{~d}-2), 11$ and $23 \mathrm{~h}(\mathrm{~d} 1), 35$ and $47 \mathrm{~h}(\mathrm{~d} \mathrm{2})$, and 59 and $71 \mathrm{~h} \mathrm{(d} \mathrm{3)} \mathrm{relative} \mathrm{to} \mathrm{initiation}$ of treatments and feed restriction. Milk production data of $d-2$ relative to initiation of each experimental period were considered as the preinfusion baseline, because data from $d-1$ could have been affected by stress linked to catheterizations. Additional milk samples were collected $12 \mathrm{~d}$ after initiation of each period, which corresponds to $9 \mathrm{~d}$ relative to termination of treatments and feed restriction. Milk samples were analyzed for fat, protein, lactose, urea nitrogen, and SCC (AgSource Milk Analysis Laboratory, Menomonie, WI) by midinfrared spectrometry (FT6000, Foss Electric, Hillerød, Denmark), and weighted daily means were computed according to a.m./p.m. milk production.

\section{Calculations and Statistical Analyses}

Calculations of glucose clearance rate $(\% / \mathrm{min})$ and time to reach half glucose concentration ( $\mathrm{min}$ ) during ivGTT, and glucose, NEFA, and insulin areas under the 
curve (AUC; positive incremental area) during ivGTT and ivBAC were performed as previously described (Pires et al., 2007b) after discounting for prechallenge basal concentrations. Basal concentrations were calculated by averaging values of samples collected at 15 and $5 \mathrm{~min}$ before ivGTT or ivBAC. These ivGTT and ivBAC measurements were analyzed using the MIXED procedure of SAS (version 9.1; SAS Institute Inc., Cary, NC). The models included the random effects of cow within sequence, period and group of cows, and the fixed effects of sequence and treatment, with KenwardRoger adjustment for calculation of denominator degrees of freedom. Period was treated as a fixed effect for DMI and milk production data. For the study of repeated measures, time and treatment $\times$ time interaction were added to the model. Group was initially included in the model for all variables but was removed because it was not significant $(P>0.25)$. The Schwarz's Bayesian criterion was used to compare the fitting of different covariance structures, including autoregressive (1), heterogeneous autoregressive (1), and compound symmetry, as well as heterogeneous variance across treatments. Spatial power structure was also tested for data collected during ivGTT and ivBAC to allow for unequal sampling intervals. Intake and production data collected after termination of treatments were analyzed separately.

All values reported are least squares means and standard errors of the mean (SEM) unless otherwise stated. Logarithmic transformation was used as needed to comply with the assumptions of normality and homoscedasticity of residuals. When transformation was needed, least squares means and SEM were estimated from untransformed values, whereas $P$-values reflect statistical analysis of transformed data. The significance level was predefined at $P \leq 0.05$, and trends toward significance were considered at $0.05<P \leq 0.10$. Treatment differences at individual time points were assessed using the SLICE option when treatment by time interaction was significant.

\section{RESULTS AND DISCUSSION}

\section{Preinfusion and Infusion Periods}

Dry matter intake was restricted from $24.1 \mathrm{~kg} / \mathrm{d}$ to $8.2,8.0$, and $8.0 \mathrm{~kg}$ on $\mathrm{d} 1,2$, and 3 of each period (per design; Table 1, Figure 1A), which induced a rapid decrease in milk yield (Table 1, Figure 2A). Plasma NEFA concentration was increased relative to baseline at $24 \mathrm{~h}$ of feed restriction and thereafter for both treatments $(P<0.001)$, but plasma NEFA was lower for NA than control throughout the infusion period (Table 2), indicating that NA inhibited lipolysis. Serum insulin was greater for NA than control at 48 and $72 \mathrm{~h}$. Despite this increase in insulin, plasma glucose was significantly greater at $72 \mathrm{~h}$ for cows receiving NA (Table 2). Plasma BHB concentrations in samples collected at 48 and 72 $\mathrm{h}$ were lower $(P<0.01)$ when cows received NA (Table 2 ), which is in agreement with the NEFA, glucose, and insulin data (Table 2).

Glucose concentration before ivGTT (at $48 \mathrm{~h}$ of feed restriction; Table 2) did not differ across treatments $(P=0.16)$, but NA led to a greater glucose peak and greater glucose AUC during ivGTT (Table 3, Figure $3 \mathrm{~A}$ ), despite greater insulin concentrations before and after glucose infusion for ivGTT (Tables 2 and 3, Figure $3 \mathrm{~B}$ ). The greater peak glucose concentration during ivGTT (Table 3, Figure 3A) is in agreement with results obtained following short-term NA infusions (Pires et al., 2007a) and may indicate a smaller distribution volume after NA infusions. This could result from decreased plasma volume due to dehydration, because urine is the main excretion route when supraphysiologic doses of NA are administered (Waterman and Schultz, 1972). Nonetheless, water intake increased linearly when lactating cows received up to $12 \mathrm{~g} / \mathrm{d}$ of a rumen-protected form of niacin (Rungruang et al., 2014), signs of dehydration were not observed in the current experiment, and water was available at all times. Glucose uptake by peripheral tissues was probably downregulated by long-term NA administration because the glucose clearance rate was unchanged despite a greater insulin response with NA. These patterns of glucose and insulin concentrations reflect a state of insulin resistance when cows received long-term NA infusions. They contrast with a previous short-term (up to $11 \mathrm{~h}$ ) experiment with feed-restricted nonlactating cows in which NA infusion at twice this rate enhanced glucose peak but also glucose clearance rate, despite a lower insulin response to ivGTT compared with control (Pires et al., 2007a). We detected a treatment effect on plasma NEFA concentration during ivGTT (590 vs. $260 \pm 70 \mu \mathrm{Eq} / \mathrm{L}$ for water and NA, respectively; $P<0.001$ ), and a tendency for a treatment by time interaction $(P=0.08$; Figure $3 \mathrm{C})$ despite marked pattern differences in plasma NEFA between treatments during ivGTT. The decrease in plasma NEFA during ivGTT was expected due to the insulin response to glucose administration and is in agreement with previous results (Pires et al., 2007a).

Dairy cows experience a sharp plasma NEFA increase at calving that is concomitant with a rapid accumulation of liver triglyceride (Vazquez-Añon et al., 1994). One objective of this experiment was to assess whether NA would attenuate the plasma NEFA surge induced by the acute lipolytic effect of ivBAC. This approach could then be used in research as an animal model to study ramifications of elevated plasma NEFA and 
Table 1. Dry matter intake and effects of continuous abomasal infusion of water or nicotinic acid (NA; $3 \mathrm{mg} / \mathrm{h}$ per $\mathrm{kg}$ of BW) on milk and milk component secretion ${ }^{1}$

\begin{tabular}{|c|c|c|c|c|c|c|c|c|c|}
\hline \multirow[b]{2}{*}{ Item } & \multirow[b]{2}{*}{ Day $^{2}$} & \multicolumn{2}{|c|}{ Treatment } & \multirow[b]{2}{*}{ SEM } & \multicolumn{5}{|c|}{$P$-value } \\
\hline & & Water & NA & & Sequence & Period & Time & Treatment & $\begin{array}{l}\text { Treatment } \\
\times \text { time }\end{array}$ \\
\hline $\begin{array}{l}\text { DMI } \\
(\mathrm{kg} / \mathrm{d})\end{array}$ & $\begin{array}{l}\text { Basal } \\
1 \\
2 \\
3\end{array}$ & $\begin{array}{r}24.0 \\
8.2 \\
7.9 \\
8.0\end{array}$ & $\begin{array}{r}24.1 \\
8.2 \\
8.0 \\
8.1\end{array}$ & 1.1 & 0.08 & 0.15 & $<0.001$ & 0.91 & 1.00 \\
\hline $\begin{array}{l}\text { Fat yield } \\
(\mathrm{kg} / \mathrm{d})\end{array}$ & $\begin{array}{l}-2 \\
1 \\
2 \\
3\end{array}$ & $\begin{array}{l}1.240 \\
1.039^{\mathrm{a}} \\
0.874^{\mathrm{a}} \\
0.809^{\mathrm{a}}\end{array}$ & $\begin{array}{l}1.176 \\
0.849^{\mathrm{b}} \\
0.608^{\mathrm{b}} \\
0.540^{\mathrm{b}}\end{array}$ & 0.085 & 0.11 & 0.35 & $<0.001$ & $<0.001$ & 0.01 \\
\hline $\begin{array}{l}\text { Protein } \\
\text { yield } \\
(\mathrm{kg} / \mathrm{d})\end{array}$ & $\begin{array}{l}-2 \\
1 \\
2 \\
3\end{array}$ & $\begin{array}{l}0.934 \\
0.766 \\
0.578^{\mathrm{a}} \\
0.555^{\mathrm{a}}\end{array}$ & $\begin{array}{l}0.921 \\
0.684 \\
0.466^{\mathrm{b}} \\
0.388^{\mathrm{b}}\end{array}$ & 0.057 & 0.21 & 0.27 & $<0.001$ & 0.002 & 0.01 \\
\hline $\begin{array}{l}\text { MUN } \\
(\mathrm{mg} / \mathrm{dL})\end{array}$ & $\begin{array}{l}-2 \\
1 \\
2 \\
3\end{array}$ & $\begin{array}{l}10.5 \\
12.7^{\mathrm{B}} \\
12.8^{\mathrm{b}} \\
11.6^{\mathrm{b}}\end{array}$ & $\begin{array}{l}12.5^{\mathrm{A}} \\
16.7^{\mathrm{a}} \\
19.1^{\mathrm{a}} \\
17.8^{\mathrm{a}}\end{array}$ & 1.4 to 2.0 & 0.55 & 0.03 & 0.008 & 0.01 & 0.38 \\
\hline $\begin{array}{l}\mathrm{SCC} \\
(\times 1,000 \text { cells } / \\
\mathrm{mL})\end{array}$ & $\begin{array}{l}-2 \\
1 \\
2 \\
3\end{array}$ & $\begin{array}{l}135 \\
136 \\
200 \\
187^{\mathrm{b}}\end{array}$ & $\begin{array}{l}127 \\
128 \\
176 \\
848^{\mathrm{a}}\end{array}$ & 185 to 286 & 0.56 & 0.20 & 0.001 & 0.62 & 0.04 \\
\hline
\end{tabular}

${ }^{\mathrm{a}, \mathrm{b}}$ Means within the same row with unlike superscripts differ $(P<0.05)$

${ }^{\mathrm{A}, \mathrm{B}}$ Means within the same row with unlike superscripts tend to differ $(P=0.06)$.

${ }^{1}$ Cows were feed restricted to $33 \%$ of ad libitum (basal) DMI ( $\mathrm{n}=8$ per treatment in a crossover design).

${ }^{2}$ Days relative to initiation of feed restriction; basal DMI was measured from d 7 to 3 before initiation of feed restriction.

be applied in the field to modulate the metabolism of periparturient dairy cows. Under the experimental conditions of the present study, NA infusion did not inhibit or attenuate the plasma NEFA response to ivBAC (Table 4, Figure 4A and B). In fact, despite the lower plasma NEFA peak after ivBAC for NA than control, NEFA AUC was greater when cows received NA (Table 4; Figure 4A). When analyzing the delta of NEFA relative to baseline value (Figure $4 \mathrm{~B}$ ), no treatment effects were observed for peak delta NEFA concentrations, and treatments differed only at $30 \mathrm{~min}$ postchallenge and thereafter. Therefore, delta NEFA profiles suggest that NA infusion did not alter lipolytic effects of ivBAC, but instead may have changed the utilization of fatty acids previously released to the blood stream. Furthermore, glucose and insulin concentrations were greater for NA than control before (at $72 \mathrm{~h}$ of feed restriction; Table 2) and after ivBAC (Table 4, Figures 4C and D). The antilipolytic effects of both elevated insulin and NA were not sufficient to counterbalance the lipolytic action of ivBAC. Others found that NEFA response to epinephrine challenges was not altered when midlactation cows received abomasal infusions of $12 \mathrm{~g} / \mathrm{d}$ of an encapsulated form of NA (Cardoso et al., 2011). One-day infusion of NA at a rate of $16 \mathrm{~g} / \mathrm{d}$ decreased plasma NEFA at 8 min post-ivBAC, whereas an infusion rate of $8 \mathrm{~g} / \mathrm{d}$ failed to alter the NEFA response (Titgemeyer et al., 2011b). Cows in the current study received $50 \pm 4.5 \mathrm{~g} / \mathrm{d}$ of $\mathrm{NA}$ (mean $\pm \mathrm{SD}$ ) but the dose of $\beta$-agonist was twice that used by Titgemeyer et al. (2011b). It is possible that this dose may have been too high to allow detection of treatment effects on peak NEFA increase in response to ivBAC.

Nicotinic acid has been used to treat human dyslipidemia, and high doses of NA may alter glycemic control. This effect has been attributed to transient rebounds of plasma NEFA following daily intake of NA boluses (Miller, 2003). In ruminants, glucose tolerance and response to insulin are impaired during NA-induced NEFA rebound (Thornton and Schultz, 1980), which is in agreement with a role of elevated plasma NEFA on induction of insulin resistance in dairy cows (Pires 
Table 2. Blood nonesterified fatty acid (NEFA), glucose, insulin, and BHB concentrations during feed restriction (33\% of ad libitum DMI) and continuous abomasal infusion of water or nicotinic acid (NA; $3 \mathrm{mg} / \mathrm{h}$ per $\mathrm{kg}$ of BW) to lactating cows ${ }^{1}$

\begin{tabular}{|c|c|c|c|c|c|c|c|c|}
\hline Item & Hour & Water & NA & SEM & Sequence & Time & Treatment & $\begin{array}{c}\text { Treatment } \times \\
\text { Time }\end{array}$ \\
\hline NEFA $(\mu \mathrm{Eq} / \mathrm{L})$ & $\begin{array}{l}0 \\
24 \\
48 \\
72\end{array}$ & $\begin{array}{l}173 \\
689^{\mathrm{a}} \\
899^{\mathrm{a}} \\
701^{\mathrm{a}}\end{array}$ & $\begin{array}{l}160 \\
393^{\mathrm{b}} \\
330^{\mathrm{b}} \\
320^{\mathrm{b}}\end{array}$ & 101 & 0.25 & $<0.001$ & $<0.001$ & 0.005 \\
\hline Insulin $(\mu \mathrm{IU} / \mathrm{mL})$ & $\begin{array}{l}0 \\
24 \\
48 \\
72\end{array}$ & $\begin{array}{l}9.5 \\
4.4 \\
4.4^{\mathrm{b}} \\
3.0^{\mathrm{b}}\end{array}$ & $\begin{array}{c}8.1 \\
7.1 \\
13.4^{\mathrm{a}} \\
23.2^{\mathrm{a}}\end{array}$ & $\begin{array}{l}1.3 \text { to } \\
2.4\end{array}$ & 0.06 & 0.03 & 0.001 & $<0.001$ \\
\hline $\mathrm{BHB}(\mathrm{mg} / \mathrm{dL})$ & $\begin{array}{l}48 \\
72\end{array}$ & $\begin{array}{l}10.8^{\mathrm{a}} \\
10.5^{\mathrm{a}}\end{array}$ & $7.2^{\mathrm{b}}$ & 1.0 & 0.94 & 0.82 & 0.006 & 0.83 \\
\hline
\end{tabular}

a,b Means within the same row with unlike superscripts differ $(P<0.05)$.

${ }^{\mathrm{A}, \mathrm{B}}$ Means within the same row with unlike superscripts tend to differ $(P<0.10)$.

${ }^{1}$ Values at 48 and $72 \mathrm{~h}$ of feed restriction correspond to the average concentrations of samples collected before i.v. glucose tolerance test and $\beta$-agonist challenge, respectively. $\mathrm{n}=8$ per treatment in a crossover design, except at $48 \mathrm{~h}$ when $\mathrm{n}=7$.

et al., 2007a,b). Because continuous NA infusions were used to decrease plasma NEFA concentrations throughout this study, other mechanisms must have been involved in the establishment of an insulin resistance state by NA. Accordingly, gradual increases in glucose and insulin occurred when steers were infused postruminally with $16 \mathrm{~g} / \mathrm{d}$ of NA, but DMI was depressed and plasma NEFA increased, leading to discontinuation of treatments after $3 \mathrm{~d}$ of NA infusion (Titgemeyer et al., 2011b). Additionally, unexplained variations in metabolic profile were found during long-term NA infusions, which raised suspicions of possible toxic NA effects (Pescara et al., 2010). Earlier research testing continuous low-rate abomasal infusions of NA (6 g/d) did not

Table 3. Effects of continuous abomasal infusion of water or nicotinic acid (NA; $3 \mathrm{mg} / \mathrm{h}$ per $\mathrm{kg}$ of BW) on i.v. glucose tolerance test (ivGTT) measurements

\begin{tabular}{|c|c|c|c|c|c|}
\hline \multirow[b]{2}{*}{ Item } & \multicolumn{2}{|c|}{ Treatment } & \multirow[b]{2}{*}{ SEM } & \multicolumn{2}{|c|}{$P$-value } \\
\hline & $\begin{array}{c}\text { Water } \\
\text { (high NEFA) }\end{array}$ & $\begin{array}{c}\text { NA } \\
\text { (low NEFA) }\end{array}$ & & Sequence & Treatment \\
\hline \multicolumn{6}{|l|}{ Glucose } \\
\hline $\operatorname{Peak}^{2}(\mathrm{mg} / \mathrm{dL})$ & 145.8 & 162.5 & 6.7 & 0.92 & 0.009 \\
\hline $\mathrm{CR}_{60}{ }^{3}(\% / \mathrm{min})$ & 2.45 & 2.36 & 0.33 & 0.44 & 0.65 \\
\hline Half-life (min) & 38.6 & 31.2 & 4.4 & 0.40 & 0.48 \\
\hline \multicolumn{6}{|l|}{ Insulin } \\
\hline $\operatorname{Peak}^{6}(\mu \mathrm{IU} / \mathrm{mL})$ & 47.4 & 84.3 & 8.6 & 0.14 & 0.007 \\
\hline $\mathrm{AUC}_{60}[(\mu \mathrm{IU} / \mathrm{mL}) \times 60 \mathrm{~min}]$ & 1,933 & 3,546 & 645 & 0.35 & 0.006 \\
\hline $\mathrm{AUC}_{180}[(\mu \mathrm{IU} / \mathrm{mL}) \times 180 \mathrm{~min}]$ & 2,502 & 6,042 & 983 & 0.25 & 0.004 \\
\hline \multicolumn{6}{|l|}{ Nonesterified fatty acid (NEFA) } \\
\hline $\mathrm{AUC}_{0}[(\mu \mathrm{Eq} / \mathrm{L}) \times 60 \mathrm{~min}]$ & -21.878 & -4.589 & 3,239 to 4.746 & 0.70 & 0.006 \\
\hline $\mathrm{AUC}_{180}[(\mu \mathrm{Eq} / \mathrm{L}) \times 180 \mathrm{~min}]$ & $-62,185$ & $-16,178$ & 7,994 to 14,765 & 0.90 & 0.02 \\
\hline
\end{tabular}

${ }^{1}$ The ivGTT $(0.25 \mathrm{~g} / \mathrm{kg}$ of BW of glucose i.v.) was performed after $48 \mathrm{~h}$ of partial feed restriction (33\% of ad libitum DMI) and continuous abomasal infusion of water or NA to lactating cows ( $\mathrm{n}=7$ per treatment in a crossover design).

${ }^{2}$ Maximum glucose concentration increase above baseline (estimated with PROC NLIN).

${ }^{3}$ Clearance rate during first $60 \mathrm{~min}$ of ivGTT.

${ }^{4}$ Area under the curve during first 60 min of ivGTT.

${ }^{5}$ Area under the curve during 180 min of ivGTT.

${ }^{6}$ Maximum insulin concentration observed during ivGTT. 


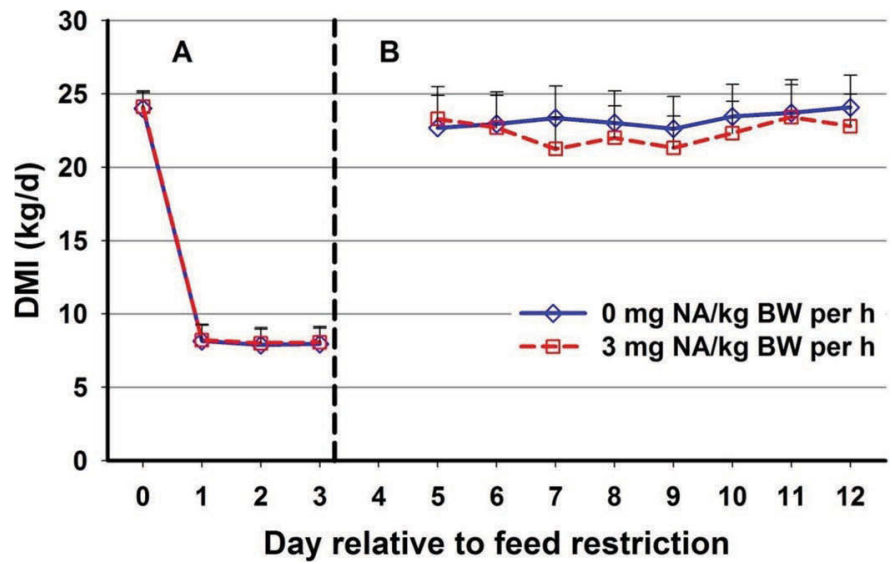

Figure 1. Effects of partial feed restriction and continuous abomasal infusion of water (control) or nicotinic acid (NA; $3 \mathrm{mg} / \mathrm{h}$ per $\mathrm{kg}$ of BW) on DMI. From 0 to $74 \mathrm{~h}$ of each experimental period, cows were feed-restricted to $33 \%$ of the ad libitum intake recorded during the prior $5 \mathrm{~d}(\mathrm{~d}-7$ to -3$)$. Nicotinic acid was used as antilipolytic agent to induce low plasma nonesterified fatty acid concentration during feed restriction. (A) Time zero corresponds to the average DMI recorded from $\mathrm{d}-7$ to -3 relative to initiation of treatments and feed restriction. Fixed effects in the statistical model: sequence $(P=0.08)$, period $(P=0.15)$, treatment $(P=0.91)$, time $(P<0.001)$, and treatment $\times$ time $(P=1.00)$. (B) DMI after refeeding. Fixed effects in the statistical model: sequence $(P=0.23)$, period $(P<0.03)$, treatment $(P=$ $0.52)$, time $(P=0.91)$, and treatment $\times$ time $(P=0.93)$. Feed intake was not recorded on d $4 . \mathrm{n}=8$ per treatment in a crossover design. Values are LSM \pm SEM. Color version available online.

find changes in basal glucose or insulin concentrations, but NA affected glucose tolerance and caused insulin resistance during ivGTT and ivBAC, with no change of NEFA responses to ivBAC (Chilliard and Ottou, 1995). Recent experiments testing a rumen-protected form of NA did not find treatment differences in postpartum plasma glucose or insulin (Morey et al., 2011; Yuan et al., 2012). Results from the current experiment and others (Titgemeyer et al., 2011b), together with the expression of NA receptors in organs other than adipose tissue in the bovine (Titgemeyer et al., 2011a), suggest that long-term administration of high doses of NA has an antilipolytic effect but also alters multiple aspects of energy metabolism by unknown mechanisms.

As expected, reduction of plasma NEFA concentration by NA led to significantly lower milk and milk component yields (Tables 1 and 2), probably reflecting limited endogenous supply of fatty acids as a substrate for energy and milk fat synthesis. Milk urea $\mathrm{N}$ content increased during feed restriction compared with when cows were eating ad libitum $(11.5,14.7,15.9$, and 14.7 $\pm 1.5 \mathrm{mg} / \mathrm{dL}$ on $\mathrm{d}-2,1,2$, and 3 relative to initiation of partial feed restriction, respectively; $P<0.01$ ). We detected a period effect on MUN (16.0 vs. $12.4 \pm$ $1.4 \mathrm{mg} / \mathrm{dL}$ for periods 1 and 2, respectively; $P=0.03$; Table 1). Milk urea $\mathrm{N}$ tended to be greater on $\mathrm{d} 1$ and

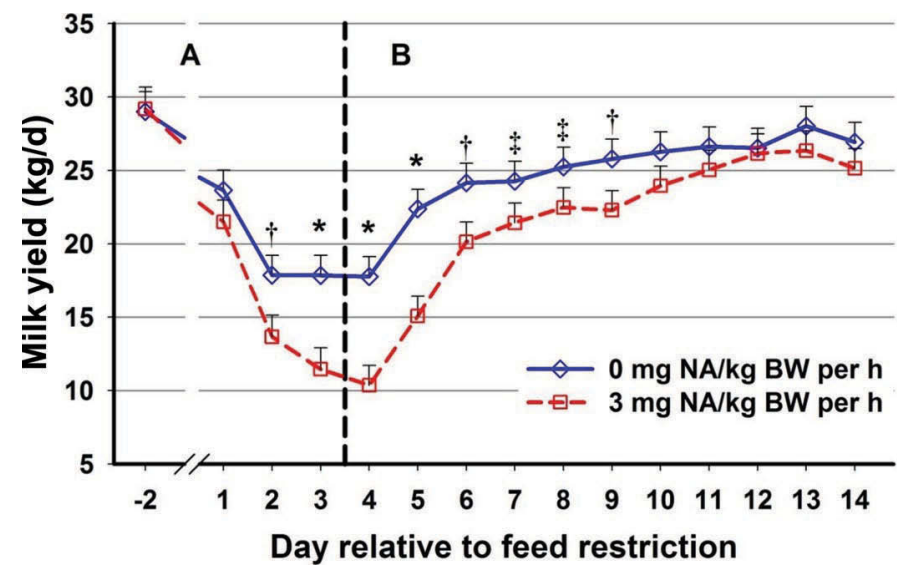

Figure 2. Effects of partial feed restriction and continuous abomasal infusion of water (control) or nicotinic acid (NA; $3 \mathrm{mg} / \mathrm{h}$ per $\mathrm{kg}$ of BW) on milk production. From 0 to $74 \mathrm{~h}$ of each experimental period, cows were feed restricted to $33 \%$ of ad libitum intake and nicotinic acid was used as antilipolytic agent to induce low plasma nonesterified fatty acid concentration. (A) Immediately prior to and during feed restriction and treatments. Fixed effects in the statistical model: sequence $(P=0.07)$, period $(P=0.67)$, treatment $(P=0.004)$, time $(P$ $<0.001)$ and treatment $\times$ time $(P=0.004)$. $P$-values reflect statistical analysis with log-transformed data. (B) After refeeding. Fixed effects in the statistical model: sequence $(P=0.04)$, period $(P<0.001)$, treatment $(P<0.001)$, time $(P<0.001)$ and treatment $\times$ time $(P=$ $0.01)$. Treatment differences within a time point are indicated by $* P$ $<0.001, \dagger P<0.01$, and $\ddagger P<0.05$. $\mathrm{n}=8$ per treatment in a crossover design. Values are LSM \pm SEM. Color version available online.

was significantly increased on d 2 and d 3 when cows received NA compared with control (Table 1). Increased MUN indicates a greater reliance on mobilized amino acids for energy and gluconeogenesis because DMI did not differ across treatments and all animals received the same diet. Therefore, increased glucose concentration observed when underfed cows received NA may have been supported, in part, by mobilization of amino acids. This effect was not expected, and the underlying mechanisms are unknown but probably involve establishment of an insulin resistant state, as suggested by glucose and insulin profiles during feed restriction, ivGTT, and ivBAC (Tables 2, 3, and 4).

Period effects were not observed for DMI or milk and milk component yields during feed restriction and infusion of treatments (Table 1). There was no difference in basal feed intake (22.9 vs. $25.3 \pm 1.5 \mathrm{~kg} \mathrm{DMI} / \mathrm{d}$; $P=0.20)$ or basal milk yield (27.8 vs. $30.4 \pm 2.53$ $\mathrm{kg} / \mathrm{d} ; P=0.34$ ) before initiation of periods 1 and 2 , respectively. Absence of period effects shows that 15 d was sufficient to allow recovery from feed restriction. Before the beginning of experiment 1, cows were blocked by BCS and breed and subsequently assigned to a sequence of treatments. By chance, cows assigned to the sequence water-NA were producing $4.8 \mathrm{~kg}$ more milk immediately before period 1 than cows assigned 

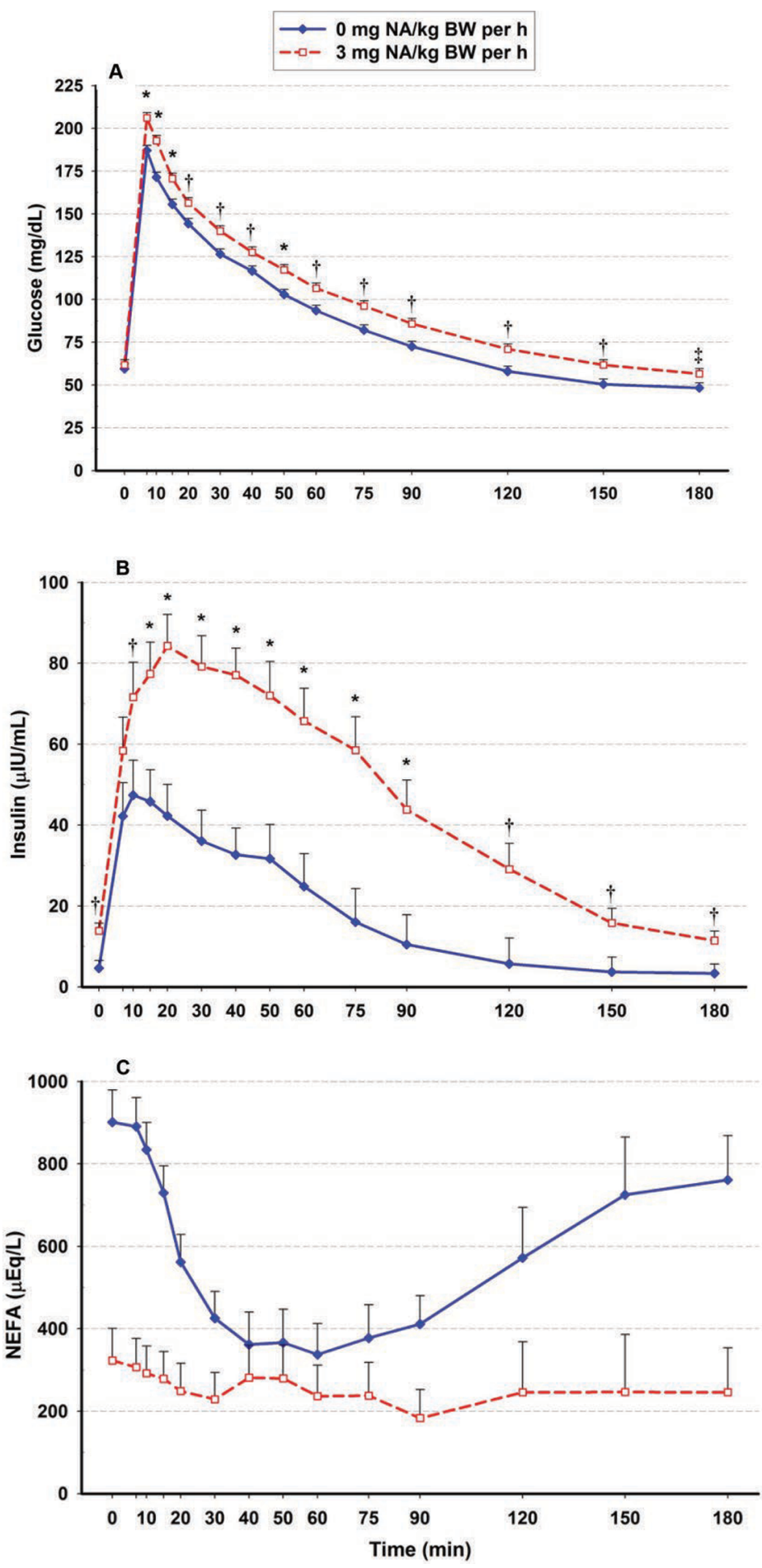

Figure 3. (A) Effects of continuous abomasal infusion of water (control) or nicotinic acid (NA; $3 \mathrm{mg} / \mathrm{h}$ per $\mathrm{kg}$ of BW) on plasma glucose concentration during i.v. glucose tolerance test (ivGTT) in lactating cows. Nicotinic acid was used as antilipolytic agent to induce low plasma nonesterified fatty acid (NEFA) concentration. The ivGTT $(0.25 \mathrm{~g} / \mathrm{kg}$ of BW of glucose i.v.) was performed $48 \mathrm{~h}$ after initiation of treatments and feed restriction to $33 \%$ of ad libitum intake. Fixed effects in the statistical model: sequence $(P=0.11)$, treatment $(P<0.001)$, time $(P<$ $0.001)$, and treatment $\times$ time $(P<0.01)$. (B) Effects of treatments on plasma insulin concentration during ivGTT. Fixed effects in the statistical model: sequence $(P=0.14)$, treatment $(P<0.001)$, time $(P<0.001)$, and treatment $\times$ time $(P<0.01)$. (C) Effects of treatments on plasma NEFA concentration during ivGTT. Fixed effects in the statistical model: sequence $(P=0.47)$, treatment $(P<0.001)$, time $(P<0.001)$, and treatment $\times$ time $(P=0.08)$. $P$-values reflect statistical analysis with log-transformed insulin and NEFA data. Treatment differences within a time point are indicated by $* P<0.001, \dagger P<0.01$, and $\ddagger P=0.05 . \mathrm{n}=7$ per treatment in a crossover design. Values are LSM \pm SEM. Color version available online. 
to the sequence NA-water $(30.2$ vs. $25.4 \pm 4.1 \mathrm{~kg} / \mathrm{d} ; P$ $=0.09)$, with a corresponding difference in DMI (25.1 vs. $20.6 \pm 1.3 \mathrm{~kg} / \mathrm{d} ; P=0.05)$. This difference in milk production and DMI preceded the administration of treatments in period 1 . Therefore, statistical trends for sequence effect on DMI, milk and lactose yields (Table 1 ), and insulin concentration ( 7.2 vs. $11.1 \pm 1.3 \mu \mathrm{IU} /$ $\mathrm{mL}$; Table 2) during the $72 \mathrm{~h}$ of treatments were not related to treatment sequence. Somatic cell count was increased on d 3 when cows received NA $(P<0.05$; Table 1). One cow receiving NA was diagnosed with clinical mastitis on d 3 of period 1 ( $\mathrm{SCC}>4,200,000$ cells $/ \mathrm{mL}$ ). This animal was treated and had recovered before the beginning of period 2 (SCC 197,000 cells/ $\mathrm{mL}$ ). Another cow that received NA during period 1 showed an increase in SCC from 268,000 cells/mL on d 2 to 613,000 cells $/ \mathrm{mL} \mathrm{SC}$ on d 3. A different cow receiving NA had an $\mathrm{SCC}>1,000,000$ cells $/ \mathrm{mL}$ on $\mathrm{d} 3$ of period 2. Also during period 2, a cow had an SCC of 3,138,000 cells/mL in milk samples collected $9 \mathrm{~d}$ after termination of NA infusion. Residual effects on SCC were not observed at the beginning of period 2 (data not shown). Treatment effects on SCC may indicate altered immune function due to feed restriction plus NA, but caution must be taken interpreting this relationship due to the small number of animals and because indicators of immune function were not assessed in the current study.

\section{Postinfusion Refeeding Period}

Despite $3 \mathrm{~d}$ of partial feed restriction during which cows were offered only $33 \%$ of the ad libitum DMI, there were no time, treatment, or treatment by time effects on intake recovery after termination of treatments (Figure 1B). Nonetheless, $74 \mathrm{~h}$ of NA infusion had negative residual effects on milk yield during the $6 \mathrm{~d}$ following termination of feed restriction and infusions (Figure 2B). Postinfusion DMI and milk yield were lower in period 2 compared with period 1 [21.2 vs. $24.4 \pm 1.9 \mathrm{~kg}$ of DMI per day $(P=0.03)$ and $22.3 \mathrm{vs}$. $24.3 \pm 1.1 \mathrm{~kg}$ of milk per day $(P<0.001)$ for periods 2 and 1, respectively]. Despite period effects, residual treatment differences were not observed for milk yield and composition on d 9 after termination of infusions and feed restriction (data not shown).

\section{CONCLUSIONS}

Patterns of glucose and insulin concentration observed during 74 -h infusion of NA $(3 \mathrm{mg} / \mathrm{h}$ per $\mathrm{kg}$ of BW), ivGTT, and ivBAC reflected a state of insulin resistance. Administration of $\mathrm{NA}$ at the rate used during this experiment $(3 \mathrm{mg} / \mathrm{h}$ per $\mathrm{kg}$ of $\mathrm{BW})$ did not inhibit the acute lipolytic effect of isoproterenol (4 nmol/kg of BW) during partial feed restriction. Greater milk urea N when cows received NA probably reflects enhanced reliance on mobilized amino acids for energy and gluconeogenesis and was concomitant with greater plasma concentrations of glucose and insulin. The underlying mechanisms regulating these adaptations are not known, but probably involve the establishment of insulin resistance when underfed lactating cows received NA, despite lower concentration of NEFA. These results contrast with previous research in which 11-h reduction of plasma NEFA concentration by

Table 4. Effects of continuous abomasal infusion of water or nicotinic acid (NA; $3 \mathrm{mg} / \mathrm{h}$ per $\mathrm{kg}$ BW) on i.v. $\beta$-agonist challenge (ivBAC) measurements ${ }^{1}$

\begin{tabular}{|c|c|c|c|c|c|}
\hline \multirow[b]{2}{*}{ Item } & \multicolumn{2}{|c|}{ Treatment } & \multirow[b]{2}{*}{ SEM } & \multicolumn{2}{|c|}{$P$-value } \\
\hline & $\begin{array}{c}\text { Water } \\
\text { (high NEFA) }\end{array}$ & $\begin{array}{c}\text { NA } \\
\text { (low NEFA) }\end{array}$ & & Sequence & Treatment \\
\hline $\mathrm{AUC}_{60}{ }^{2}[(\mathrm{mg} / \mathrm{dL}) \times 60 \mathrm{~min}]$ & 189 & 299 & 111 & 0.87 & 0.15 \\
\hline $\mathrm{AUC}_{120}{ }^{3}[(\mathrm{mg} / \mathrm{dL}) \times 120 \mathrm{~min}]$ & 240 & 535 & 169 & 0.82 & 0.03 \\
\hline \multicolumn{6}{|l|}{ Insulin } \\
\hline \multicolumn{6}{|l|}{ Nonesterified fatty acid (NEFA) } \\
\hline $\operatorname{Peak}^{4}(\mu \mathrm{Eq} / \mathrm{L})$ & 1,461 & 1,141 & 107 & 0.75 & 0.01 \\
\hline $\mathrm{AUC}_{60}[(\mu \mathrm{Eq} / \mathrm{L}) \times 60 \mathrm{~min}]$ & 21,167 & 34,107 & 4,154 to 6,412 & 0.24 & 0.06 \\
\hline $\mathrm{AUC}_{120}[(\mu \mathrm{Eq} / \mathrm{L}) \times 120 \mathrm{~min}]$ & 22,862 & 45,521 & 5,325 & 0.80 & 0.02 \\
\hline
\end{tabular}

${ }^{1}$ The ivBAC $(4 \mathrm{nmol} / \mathrm{kg} \mathrm{BW}$ of isoproterenol i.v.) was performed after $72 \mathrm{~h}$ of partial feed restriction (33\% of ad libitum DMI) and continuous abomasal infusion of water or NA to lactating cows ( $\mathrm{n}=8$ per treatment in a crossover design).

${ }^{2}$ Area under the curve during first $60 \mathrm{~min}$ of ivBAC.

${ }^{3}$ Area under the curve during 120 min of ivBAC.

${ }^{4}$ Maximum NEFA concentration observed during ivBAC. 

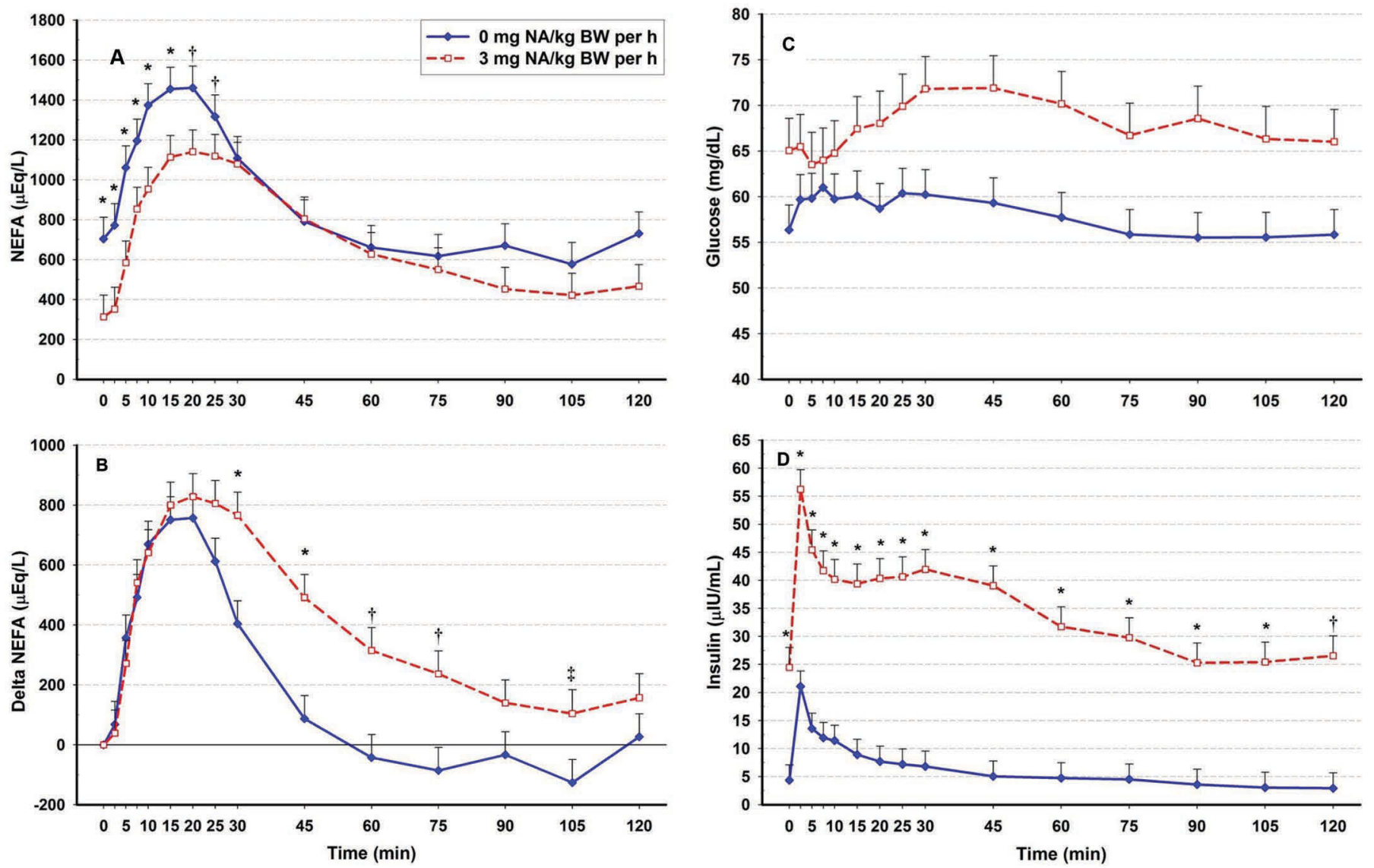

Figure 4. (A) Effects of continuous abomasal infusion of water (control) or nicotinic acid (NA; $3 \mathrm{mg} / \mathrm{h}$ per $\mathrm{kg}$ of BW) on plasma nonesterified fatty acid (NEFA) concentration during i.v. $\beta$-agonist challenge (ivBAC) in lactating cows. Nicotinic acid was used as antilipolytic agent to induce low plasma NEFA concentration. The ivBAC $(4 \mathrm{nmol} / \mathrm{kg}$ of BW of isoproterenol i.v.) was performed $72 \mathrm{~h}$ after initiation treatments and feed restriction to $33 \%$ of ad libitum intake. Fixed effects in the statistical model: sequence $(P=0.74)$, treatment $(P=0.003)$, time $(P<0.001)$, and treatment $\times$ time $(P=0.01)$. (B) Effect of treatments on plasma NEFA concentration change (delta NEFA) after ivBAC. Fixed effects in the statistical model: sequence $(P=0.65)$, treatment $(P=0.03)$, time $(P<0.001)$, and treatment $\times$ time $(P=0.009)$. Treatment differences within a time point are indicated by $* P \leq 0.001, \dagger P \leq 0.01$, and $\ddagger P<0.05$. (C) Effects of treatments on plasma glucose concentration during ivBAC. Fixed effects in the statistical model: sequence $(P=0.16)$, treatment $(P<0.001)$, time $(P=0.07)$, and treatment $\times$ time $(P=0.32)$. (D) Effects of treatments on plasma insulin concentration during ivBAC. Fixed effects in the statistical model: sequence $(P=0.13)$, treatment $(P<0.001)$, time $(P<0.001)$, and treatment $\times$ time $(P<0.01)$. $P$-values reflect statistical analysis with log-transformed data except for delta NEFA. Treatment differences within a time point are indicated by ${ }^{*} P<0.001, \dagger P \leq 0.01 . \mathrm{n}=8$ per treatment in a crossover design. Values are $\mathrm{LSM} \pm \mathrm{SEM}$. Color version available online.

NA enhanced the response to insulin in feed-restricted nonlactating cows (Pires et al., 2007a). Data suggest that long-term supraphysiological infusion of NA affects intermediary metabolism by mechanisms other than the NA antilipolytic effect.

\section{ACKNOWLEDGMENTS}

The authors thank UW-Madison Dairy Nutrition students for help during sample collection; the staff at the Dairy Cattle Instruction and Center Research for animal care, feeding, and milking; and Sandy Bertics (UW-Madison) for supervision of laboratory work. This research was partially funded by an unrestricted gift from Pfizer Animal Health (Kalamazoo, MI). J. Pires gratefully acknowledges a fellowship (SFRH/ BPD/34037/2006) from Fundação para a Ciência e a Tecnologia (Lisbon, Portugal).

\section{REFERENCES}

Allen, M. S., and P. Piantoni. 2013. Metabolic control of feed intake: Implications for metabolic disease of fresh cows. Vet. Clin. North Am. Food Anim. Pract. 29:279-297.

Bauman, D. E., and W. B. Currie. 1980. Partitioning of nutrients during pregnancy and lactation: A review of mechanisms involving homeostasis and homeorhesis. J. Dairy Sci. 63:1514-1529.

Bell, A. W., and D. E. Bauman. 1997. Adaptations of glucose metabolism during pregnancy and lactation. J. Mammary Gland Biol. Neoplasia 2:265-278. 
Cadórniga-Valiño, C., R. R. Grummer, L. E. Armentano, S. S. Donkin, and S. J. Bertics. 1997. Effects of fatty acids and hormones on fatty acid metabolism and gluconeogenesis in bovine hepatocytes. J. Dairy Sci. 80:646-656.

Cardoso, F. C., W. Sears, S. J. LeBlanc, and J. K. Drackley. 2011. Technical note: Comparison of 3 methods for analyzing areas under the curve for glucose and nonesterified fatty acids concentrations following epinephrine challenge in dairy cows. J. Dairy Sci. 94:6111-6115.

Chilliard, Y., A. Ferlay, Y. Faulconnier, M. Bonnet, J. Rouel, and F. Bocquier. 2000. Adipose tissue metabolism and its role in adaptations to undernutrition in ruminants. Proc. Nutr. Soc. 59:127-134.

Chilliard, Y., and J. F. Ottou. 1995. Duodenal infusion of oil in midlactation cows. 7. Interaction with niacin on responses to glucose, insulin, and beta-agonist challenges. J. Dairy Sci. 78:2452-2463.

Doepel, L., H. Lapierre, and J. J. Kennelly. 2002. Peripartum performance and metabolism of dairy cows in response to prepartum energy and protein intake. J. Dairy Sci. 85:2315-2334.

Ferlay, A., and Y. Chilliard. 1999. Effects of the infusion of non-selective beta-, and selective beta1- or beta2-adrenergic agonists, on body fat mobilisation in underfed or overfed non-pregnant heifers. Reprod. Nutr. Dev. 39:409-421.

Gibbard, S., and P. J. Watkins. 1968. A micro-method for the enzymatic determination of D-beta-hydroxybutyrate and acetoacetate. Clin. Chim. Acta 19:511-521.

Gressley, T. F., S. M. Reynal, J. J. O. Colmenero, G. A. Broderick, and L. E. Armentano. 2006. Technical Note: Development of a tool to insert abomasal infusion lines into dairy cows. J. Dairy Sci. 89:3965-3967.

Grummer, R. R. 1993. Etiology of lipid-related metabolic disorders in periparturient dairy cows. J. Dairy Sci. 76:3882-3896.

Hayirli, A., R. R. Grummer, E. V. Nordheim, and P. M. Crump. 2003. Models for predicting dry matter intake of Holsteins during the prefresh transition period. J. Dairy Sci. 86:1771-1779.

Lacetera, N., D. Scalia, O. Franci, U. Bernabucci, B. Ronchi, and A. Nardone. 2004. Short communication: Effects of nonesterified fatty acids on lymphocyte function in dairy heifers. J. Dairy Sci. $87: 1012-1014$.

Miller, M. 2003. Niacin as a component of combination therapy for dyslipidemia. Mayo Clin. Proc. 78:735-742.

Morey, S. D., L. K. Mamedova, D. E. Anderson, C. K. Armendariz, E. C. Titgemeyer, and B. J. Bradford. 2011. Effects of encapsulated niacin on metabolism and production of periparturient dairy cows. J. Dairy Sci. 94:5090-5104.

NRC. 2001. Nutrient Requirements of Dairy Cattle. 7th Revised ed. Natl. Acad. Press, Washington, DC.

Pescara, J. B., J. A. A. Pires, and R. R. Grummer. 2010. Antilipolytic and lipolytic effects of administering free or ruminally protected nicotinic acid to feed-restricted Holstein cows. J. Dairy Sci. 93:5385-5396.
Pires, J. A. A., and R. R. Grummer. 2007. The use of nicotinic acid to induce sustained low plasma nonesterified fatty acids in feedrestricted Holstein cows. J. Dairy Sci. 90:3725-3732.

Pires, J. A. A., J. B. Pescara, and R. R. Grummer. 2007a. Reduction of plasma NEFA concentration by nicotinic acid enhances the response to insulin in feed-restricted Holstein cows. J. Dairy Sci. 90:4635-4642

Pires, J. A. A., A. H. Souza, and R. R. Grummer. 2007b. Induction of hyperlipidemia by intravenous infusion of tallow emulsion causes insulin resistance in Holstein cows. J. Dairy Sci. 90:2735-2744.

Rabelo, E., R. L. Rezende, S. J. Bertics, and R. R. Grummer. 2003. Effects of transition diets varying in dietary energy density on lactation performance and ruminal parameters of dairy cows. J. Dairy Sci. 86:916-925.

Reynolds, C. K., P. C. Aikman, B. Lupoli, D. J. Humphries, and D. E. Beever. 2003. Splanchnic metabolism of dairy cows during the transition from late gestation through early lactation. J. Dairy Sci. $86: 1201-1217$.

Rungruang, S., J. L. Collier, R. P. Rhoads, L. H. Baumgard, M. J. de Veth, and R. J. Collier. 2014. A dose-response evaluation of rumen-protected niacin in thermoneutral or heat-stressed lactating Holstein cows. J. Dairy Sci. 97:5023-5034.

Strang, B. D., S. J. Bertics, R. R. Grummer, and L. E. Armentano. 1998. Effect of long-chain fatty acids on triglyceride accumulation, gluconeogenesis, and ureagenesis in bovine hepatocytes. J. Dairy Sci. 81:728-739.

Thornton, J. H., and L. H. Schultz. 1980. Effects of administration of nicotinic acid on glucose, insulin, and glucose-tolerance in ruminants. J. Dairy Sci. 63:262-268.

Titgemeyer, E. C., L. K. Mamedova, K. S. Spivey, J. K. Farney, and B. J. Bradford. 2011a. An unusual distribution of the niacin receptor in cattle. J. Dairy Sci. 94:4962-4967.

Titgemeyer, E. C., K. S. Spivey, L. K. Mamedova, and B. J. Bradford. 2011b. Effects of pharmacological amounts of nicotinic acid on lipolysis and feed intake in cattle. Int. J. Dairy Sci. 6:134-141.

Vazquez-Añon, M., S. Bertics, M. Luck, R. R. Grummer, and J. Pinheiro. 1994. Peripartum liver triglyceride and plasma metabolites in dairy cows. J. Dairy Sci. 77:1521-1528.

Veenhuizen, J. J., J. K. Drackley, M. J. Richard, T. P. Sanderson, L. D. Miller, and J. W. Young. 1991. Metabolic changes in blood and liver during development and early treatment of experimental fatty liver and ketosis in cows. J. Dairy Sci. 74:4238-4253.

Waterman, R., and L. H. Schultz. 1972. Nicotinic acid loading of normal cows: Effects on blood metabolites and excretory forms. J. Dairy Sci. 55:1511-1513.

Yuan, K., R. D. Shaver, S. J. Bertics, M. Espineira, and R. R. Grummer. 2012. Effect of rumen-protected niacin on lipid metabolism, oxidative stress, and performance of transition dairy cows. J. Dairy Sci. 95:2673-2679. 